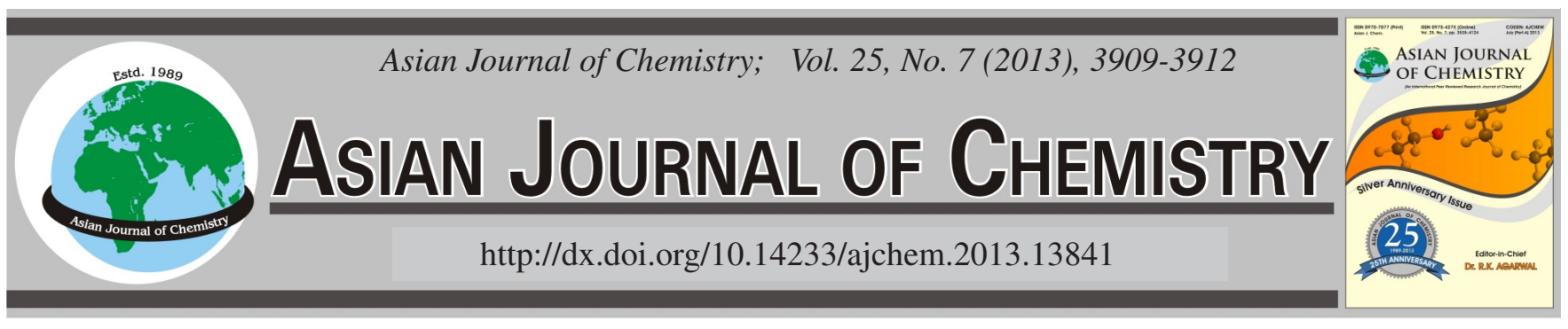

\title{
Column Studies on Effect of Phosphate Immobilization on Removal of Metals from Stormwater Runoff in Bioretention Cell
}

\begin{abstract}
V. DEMIR ${ }^{1, *}$ and S. BIN-SHAFIQUE ${ }^{2}$
${ }^{1}$ Department of Environmental Engineering, Tunceli University, Tunceli, Turkey

${ }^{2}$ Department of Civil and Environmental Engineering, The University of Texas at San Antonio, San Antonio, Texas, USA

*Corresponding author: Fax: +90 428 2131861; Tel: +90 428 2131794; E-mail: veyseldemir@tunceli.edu.tr

(Received: 4 April 2012;

Accepted: 16 January 2013)

AJC-12721

Batch studies indicated that low cost native materials such as loam soil, juniper mulch, hardwood mulch, pine mulch and sawdust performed efficiently as media in bioretention cell for removal of copper and lead from stormwater runoff. Juniper mulch performed best in batch studies was used in column studies. Column studies suggested that the presence of phosphate has a pronounced effect on metal immobilization. This is due to the formation of metal phosphates that have extremely low solubility. The remaining metals were adsorbed on bioretention media of the bioretention cell. Breakthrough adsorption and desorption curves for lead and copper were measured in presence and absence of phosphate immobilization. Copper reached a breakthrough curve in around 20 days and lead in 30 days. Column studies showed that in all samples addition of phosphate also decreased the leaching of lead and copper back to aqueous solution consistent with lead and copper immobilization.
\end{abstract}

Key Words: Bioretention, Metals, Phosphate, Stormwater.

\section{INTRODUCTION}

Heavy metal accumulation and leaching of these heavy metals to water sources are potential threats for human health. Heavy metals are the most studied toxic pollutants because of their carcinogenicity ${ }^{1}$ and detection in ground and surface waters in many urban regions throughout the country ${ }^{2}$. The dangers of heavy metals were well documented in several studies $^{3,4}$. Filtration and sorption of runoff through filter systems or bioretention cells are one of the treatment methods to remove low level heavy metals in stormwater runoff ${ }^{1,5}$.

Stormwater $\mathrm{pH}$, varying pollutant concentration, different flow intensity and duration on bioretention cell are the main factors affecting the pollutant removal characteristic of bioretention systems ${ }^{6}$. Heavy metal solubility in contaminated soils and water sources can also be reduced with chemical immobilization method using inexpensive chemicals such as organic matter (municipal biosolids, composts, manures and peat), alkaline material and phosphate fertilizers (hydroxyapatite, soluble phosphate) $)^{7}$.

Long term effectiveness and permanence are important criteria used to evaluate alternate remediation techniques ${ }^{8}$. Therefore, removal of heavy metals via bioretention has to be long term. There are numerous researches on removal of heavy metals via bioretention systems however there are limited researches on long term effectiveness and permanence of bioretention media. Immobilization of heavy metals with phosphate based fertilizers may improve long term efficiency of bioretention system with reduction in solubility and bioavailability. Bioretention systems with phosphate immobilization techniques can be possible long term treatment method to remove heavy metals in urban stormwater runoff.

The objective of this study is to evaluate the effect of the presence of phosphate in stormwater on metal removal in bioretention cell. To achieve this objective, column tests were performed in which the phosphate-based fertilizer ammonium phosphate dibasic was added to synthetic stormwater runoff and processed through juniper mulch bioretention column. The removal of heavy metal in stormwater runoff with juniper mulch packed bioretention column was investigated since juniper mulch performed best in batch studies for removal of copper and lead and the availability of juniper trees all over the Edward's Aquifer region. Overall results will help to design more efficient biological retention facilities with understanding of the roles of phosphate immobilization in the removal of lead and copper.

EXPERIMENTAL

The synthetic solution used in the experiment to simulate stormwater runoff was prepared by dissolving known amounts 
of lead(II) nitrate, copper nitrate and calcium chloride in de-ionized water. Metal salts were collected from SigmaAldrich. Native material as bioretention media, Red Shredded Juniper Mulch was obtained from Texas Native- Austin Wood Recycling, Cedar Park, Texas. 40 liters containers, all 2 L plastic containers and glassware were washed with nitric acid and de-ionized water then rinsed and filled with de-ionized water. The de-ionized (DI) water quality was checked using a HACH SENS ION 5 conductivity meter and the total dissolved solids measured $0.2 \mathrm{mg} / \mathrm{L}$. Phosphate-based fertilizer i.e., ammonium phosphate dibasic used to immobilize heavy metals in synthetic urban stormwater runoff was obtained from Scientific Lab.com, Inc, Houston, TX. Copper and lead standards for atomic absorbance spectrometer were bought from Sigma-Aldrich Chemie. Omnifit brand $25 \mathrm{~mm} \times 100$ $\mathrm{mm}$ fixed glass column assemblies were bought from Western Analytical Products, Lake Elsinore, Ca. Columns packed with Juniper mulch passed through U.S. Standard sieve number 4 (4.75 $\mathrm{mm} \times 4.75 \mathrm{~mm}$ opening).

Efficacy of immobilization of lead and copper in stormwater runoff with phosphate based fertilizer and removal capacity of juniper mulch bioretention system were investigated using column adsorption and desorption studies. Eighty liters of synthetic stormwater runoff (SW-A) was prepared based on stormwater data used by Prince George's County Department of environmental studies ${ }^{9}$ and SW-F was prepared based on Walker et al. ${ }^{10}$ 's data. Lead and copper concentration in SW-A and SW-F were adjusted to 80 and 8000 ppb, respectively. $10 \mathrm{~cm}$ long and $2.5 \mathrm{~cm}$ inner diameter columns were packed with cedar mulch by hand. Weight of packed material and pore volume were measured for each bioretention column. The flow rate was kept constant at $3 \mathrm{~mL} / \mathrm{min}$. The columns were operated in an up-flow mode ${ }^{11}$ to ensure complete mixing and to avoid side leaking. During the experiment, influent was pumped continually to the bottom of the column and effluent was collected from the top of the column every day. Each day $10 \mathrm{~mL}$ of effluent was collected and rest of it was discarded. The $\mathrm{pH}$ was measured immediately for every sample. Effluents were filtered through $0.45 \mu \mathrm{m}$ glass micro-fiber filter. The filtrates were then taken to $10 \mathrm{~mL}$ pre-washed (acid wash) air tight glass vials. $\mathrm{HNO}_{3}$ was added to filtrates to have $\mathrm{pH}$ less than two. The vials were then stored in the refrigerator for chemical analysis following EPA standard procedures. Same experiments were repeated with $8 \mathrm{mg} / \mathrm{L}$ phosphate added synthetic stormwater runoff (SW-H) containing $8000 \mathrm{ppb}$ of lead and copper.

To determine stability of removal of heavy metals by bioretention cell media and metal precipitation in the presence of phosphate, desorption (leaching) experiments were conducted. After adsorption breakthrough curves were obtained by column studies, bioretention columns were washed with deionized water until desorption breakthrough curves were obtained. Chemical analysis was performed according to EPA standard methods corresponding to specific elements using a graphite furnace atomic absorption spectrophotometer (AAS). Before metal analysis, standards and samples were acidified using trace metal grade with nitric acid. Atomic absorption modifier solution which is collected from Perkin Elmer was also added to each standard and sample before analysis. Three replicates of each sample, including equipment blank and bottle blank, were measured. If the relative standard deviation was higher than $10 \%$, the measurement was discarded and another measurement was made.

\section{RESULTS AND DISCUSSION}

Column studies were conducted to provide a realistic scenario of metal transport through the bioretention media. Columns were packed with juniper mulch by hand as good as possible. Columns contained $11.2 \mathrm{~g}$ of juniper mulch and pore volume calculated as $23 \mathrm{~mL}$. Effective porosity and bulk density of the media were measured as 0.47 and $0.48 \mathrm{~kg} / \mathrm{L}$, respectively. Eighty liters of synthetic stormwater containing $80 \mathrm{ppb}$ copper and lead were run through juniper mulch packed bioretention columns. Effluent concentrations were measured less than $8 \mathrm{ppb}$ for both copper and lead and for both cases, no breakthrough curve was observed. $\mathrm{pH}$ values of effluents were also measured for each sampling in the range of 7.31 and 7.74. Stormwater F containing 8000 ppb lead and copper was used for second set of column experiments. Identical juniper mulch packed columns were fed by stormwater F until breakthrough curve was obtained. Copper reached a breakthrough curve around 20 days and lead around 30 days.

Two identical cedar mulch packed columns were also fed with stormwater $\mathrm{H}$, containing $8 \mathrm{mg} / \mathrm{L}$ phosphate until break through curve was obtained. Initial copper and lead concentrations were measured in stormwater $F$ as $8000 \mathrm{ppb}$. In the presence of phosphate, lead and copper concentration in stormwater $\mathrm{H}$ decreased to 1822 and $3250 \mathrm{ppb}$, respectively. Breakthrough curves for effluent lead concentration for both stormwater $\mathrm{F}$ and stormwater $\mathrm{H}$ fed columns were displayed in Fig. 1. Hundred percent removal of lead was observed in 500 pore volume of stormwater F processed. After 1460 pore volume, juniper mulch media reached its removal capacity. After this point no lead removal was detected. Since presence of phosphate initially precipitated $77.2 \%$ of lead in stormwater, lower metal load was applied to columns fed by stormwater $\mathrm{H}$. This also increased the time to reach media's removal capacity. Hundred percent of lead removal was observed until 1500 pore volume of stormwater $\mathrm{H}$ was processed. Breakthrough curve was obtained based on lead content in aqueous phase after phosphate precipitation. After 2390 pore volume, mulch media reached its capacity and effluent lead concentration stayed as influent stormwater concentration of $1822 \mathrm{ppb}$.

Breakthrough curves for effluent copper concentrations were displayed in Fig. 2. Breakthrough curve for effluent copper concentration was formed faster than lead. In first 400 pore volume, $100 \%$ removal was detected, after 1100 pore volume, column reached its capacity for copper removal. No significant copper removal was detected after this point. For stormwater $\mathrm{H}$ fed column, breakthrough curve was formed based on stormwater's copper concentration after precipitation of copper with phosphate. In first 750 pore volume, $100 \%$ removal of copper was displayed and column reached its full copper removal capacity after 2070 pore volume stormwater $\mathrm{H}$ processed. 


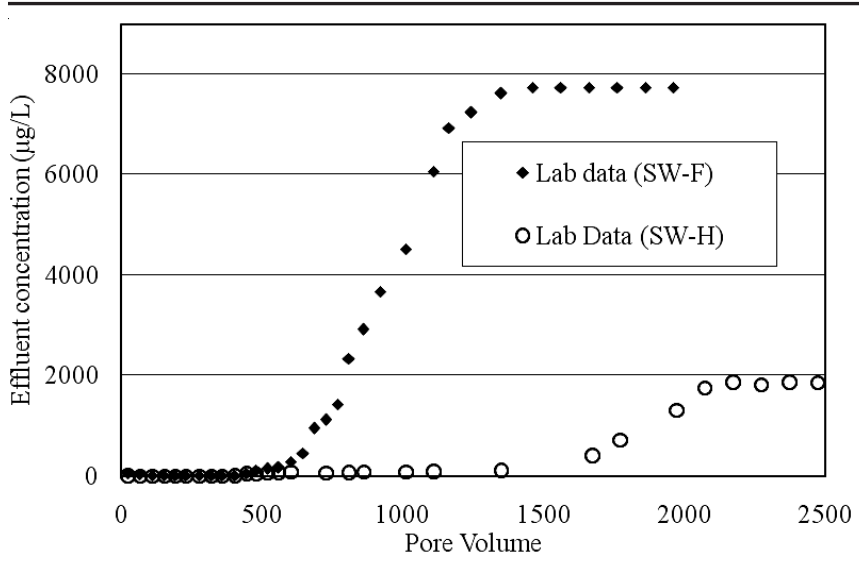

Fig. 1. Breakthrough curve for lead

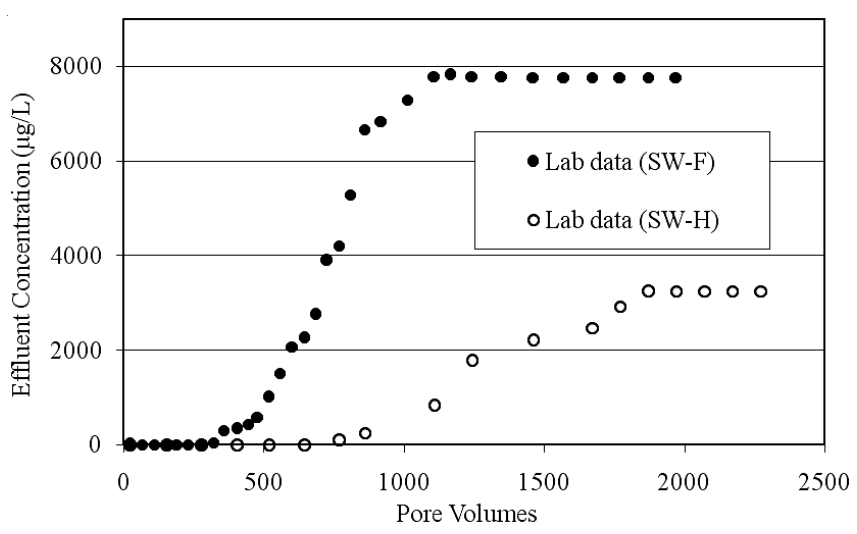

Fig. 2. Breakthrough curve for copper

Since heavy metals held in bioretention cell may leach with infiltrating rain water passing through bioretention cell, stability of these heavy metals in bioretention cell is also concern about the lifetime and efficiency of bioretention cell. To determine stability of heavy metals held by bioretention cell media, leaching experiments were conducted. After adsorption breakthrough curve was obtained by column studies, bioretention cells were washed with $40 \mathrm{~L}$ of deionized water and effluent concentrations were measured and recorded. For juniper mulch desorption column studies, small amount of copper and lead leached from bioretention cell and copper leached more than lead. After $40 \mathrm{~L}$ deionized water passed, effluent concentration became stable at less than $40 \mathrm{ppb}$ for copper and $30 \mathrm{ppb}$ for lead.

Leaching of lead and copper back to aqueous phase occurred less in stormwater $\mathrm{H}$ fed bioretention cell. This indicated that phosphate precipitation is more stable than adsorption mechanism. After $40 \mathrm{~L}$ deionized water passed, effluent concentration of lead and copper became stable less than 30 ppb for copper and $20 \mathrm{ppb}$ for lead. Copper and lead leaching curve for stormwater $\mathrm{F}$ and stormwater $\mathrm{H}$ processed columns were displayed in Figs. 3 and 4. Leaching curve indicated that, copper and lead adsorption with juniper mulch is mostly irreversible. Less than $2 \%$ of adsorped lead and copper leached out to aqueous phase.

The presence of phosphate in bioretention cell has significant effect on removal of copper and lead in bioretention cell. It is calculated that $1 \mathrm{~g}$ of mulch adsorped $106 \mathrm{mg}$ of

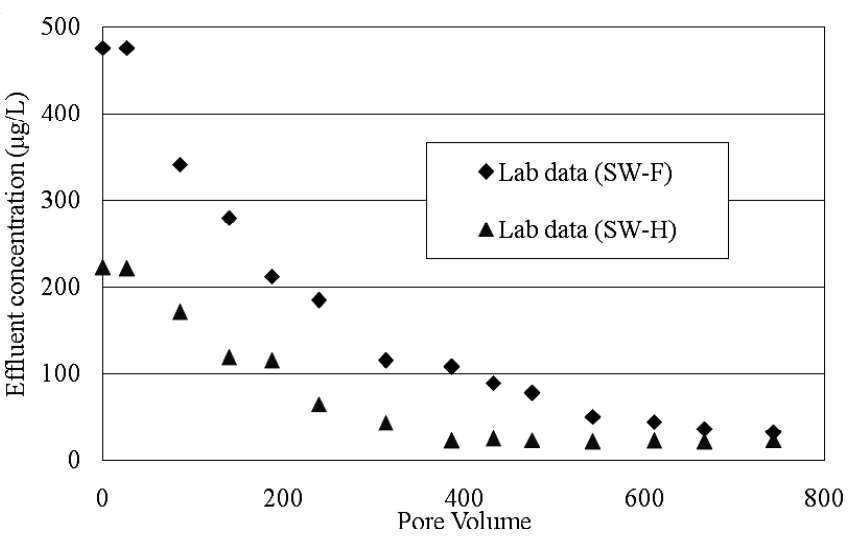

Fig. 3. Leaching of lead from bioretention media

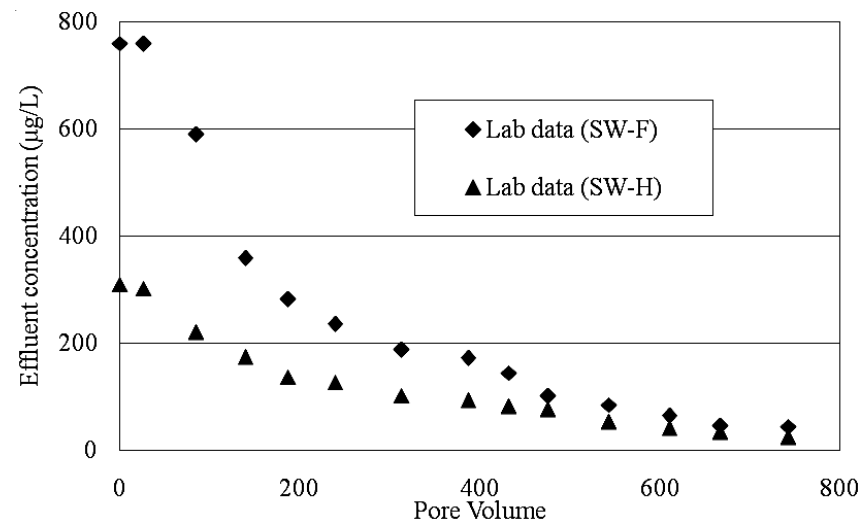

Fig. 4. Leaching of copper from bioretention media

copper and $162 \mathrm{mg}$ of lead until breakthrough. In presence of phosphate total removal increased to $278 \mathrm{mg}$ of copper and $371 \mathrm{mg} / \mathrm{g}$ of mulch media. It is calculated that $79.4 \mathrm{mg}$ of copper and $89.8 \mathrm{mg}$ of lead was adsorped until breakthrough and $199 \mathrm{mg}$ of copper and $281 \mathrm{mg}$ of lead per gram of mulch was precipitated with phosphate. Presence of phosphate increased life time of bioretention media and also decreased the final concentration of lead and copper in bioretention effluent.

\section{Conclusion}

Column studies suggested that presence of phosphate based fertilizer has prominent effect on removal of lead and copper in stormwater runoff. It also increases long term efficiency of bioretention cell and decreases the leaching of lead and copper back to water sources. The $\mathrm{pH}$ dependent leaching behaviour of bioretention system can be optimized using phosphate immobilization. Column studies showed that leaching of lead and copper in bioretention system to aqueous phase can be successfully reduced with phosphate immobilization. Phosphate immobilization improves the efficiency of bioretention system over a wide range of environmental conditions. This study showed the feasibility of phosphate application to bioretention system to enhance removal of lead and copper in stormwater runoff. Phosphate based fertilizer immobilization and characterization of media will help to design more efficient bioretention facilities. 


\section{REFERENCES}

1. Y.S. Ho, C.T. Huang and H.W. Huang, Process Biochem., 37, 1421 (2002).

2. A. Jang, S.W. Lee, Y. Seo, K.W. Kim and P.L. Bishop, Water Sci. Technol., 55, 95 (2007).

3. Z. Szitanyi, C. Nemes and N. Rozlosnik, Microchem. J., 54, 246 (1996).

4. Agency for Toxic Substances and Disease Registry (ATSDR), Toxicological Profile for Cadmium, Atlanta, GA, US EPA Department of Health and Human Service (1999).

5. A. P. Davis, M. Shokouhian and S. Ni, Chemosphere, 44, 997 (2001).

6. A.P. Davis, M. Shokouhian and H. Sharma, Water Environ. Res., 75, 73 (2003).

7. N.T. Basta, R. Gradwohl, K.L. Snethen and J.L. Schroder, J. Environ. Quality, 30, 1222 (2001).
8. P. LaForna, In eds: M.K. Richards et al., Assessing the Risk of Remedial Alternatives at Superfund sites: Implications for Technology Demonstrators, Remedial action, treatment and disposal of hazardous waste. Proc. of the 7th Annual RREL Hazardous Waste Research Sympp., Cincinnati, OH. 9-11 Apr. 1991. USEPA Repp. 600/9-91/002. Risk Reduction Eng. Lab., Office of Res. and Dev., Cincinnati, OH, pp. 488-495 (1991)

9. Prince George's County U.S. EPA Department of Environmental Resources (PGDER), Design Manual for Use of Bioretention in Stormwater Management, Division of Environmental Management, Watershed Protection Branch. Landover, MD (1993).

10. W.J. Walker, R.P. McNutt and C.A.K. Maslanka, Chemosphere, 38, 363 (1999).

11. H.A. Das, H.A. Van Der Sloot and J. Wijkstra, Toxicol. Environ. Chem., 19, 109 (1989). 